Kofo. A. Aderogba (Mrs.) and Michael. A. Obafemi / IOSR Journal of Engineering (IOSRJEN) www.iosrjen.org

ISSN : 2250-3021

\title{
Vol. 2 Issue 2, Feb.2012, pp.273-279 \\ An Incidence of Wastes and Water Pollution of Ilo Stream of Ado-Odo Ota Local Government Area of Ogun State, Nigeria
}

\author{
Kofo. A. Aderogba (Mrs.) and Michael. A. Obafemi \\ Department of Geography and Environmental Studies \\ Tai Solarin University of Education \\ Ijebu-Ode, Nigeria
}

\begin{abstract}
Ilo stream is significant for washing, drinking, fishing, industrial production, and others. But the water has been polluted by the junks and even wastes from homes, manufacturing industries, the abattoir, hotels and others around. There are various attributes and concentrations of elements, compounds, and substances that are not within the WHO permissible standards. Other alternative sources: pipe borne water, boreholes and wells, rain and packaged water and others are not common nor within the reach of many. Pollution of natural body of Ilo Stream water could be controlled and managed by individuals, groups and the governments and government agencies. At the interim, wells and boreholes should be provided to serve the communities. The treatment of effluents and wastes from the manufacturing industries before discharging into the land and water bodies is very important and should be made mandatory. Environmental Impact Assessment Decree No 86 of 1992 and Section 33 of Urban and Regional Planning Decree No 88 of 1992 should be enforced. It will ensure portability of most stream waters with little or no treatment.
\end{abstract}

Key Words: Wastes, polluted water, Ilo Stream, Environmental Impact Assessment (EIA).

\section{PREAMBLE:}

The effects of major environmental problems cannot be over emphasized; and the issue of environmental hazards is mostly and popularly traced to pollution problems, (Uchegbu, 2000). The pollution problems of the environment which need adequate management and control ranges from solid wastes, sewage wastes, air pollution, water and aquifer pollution, (Umeh and Uchegbu, 1997 : 16). These are most worrisome because they are global and the problems created by them are threat to both aquatic and terrestrial lives, and can lead to their extinctions. Though major environment problems range from pollution (of air, water and noise) to biological losses, deforestation and atmospheric contamination each has a linkage effect with another. These tend to exacerbate the effect of others thus creating waves of anxiety, worry and concern for all lovers of the environment, (Umeh, 2000: 21). This piece is concerned with wastes and water pollution as they affect Ilo stream water in Ado-Odo Ota Local Government Area of Ogun State - an adjacent Local Government Area to Ijaiye-Ojokoro Local Government Area of Lagos State, all in the humid western part of Nigeria.

In the process of using water at homes, in industries, hotels, on farms, for sanitation, recreation and others, it becomes polluted and contaminated by the various substances it comes in contact with. Also there are various substances generated at homes, in industries, on farms, in the processes of constructions and others that found their ways into the streams (and rivers). Some of such substances are directly dumped into the rivers, stream and water bodies while others were dragged through sewages, erosions and drainage gutters. By and large, the receiving body of water suffers: Some of the substances are toxic and hazardous to plants and animals including human beings. Others render the water unsuitable for any specific applications.

Such waste water and solid wastes have been discharged and or dumped directly or inadvertently into Ilo stream. Also junks, debris, refuse dumps and dung hills around the environment of the Ilo stream have compounded the pollution conditions of the stream. The water that could have been available for washing, drinking (as it used to be for local people), preparation of cow meat at the abattoirs and so many other uses appear unusable again.

However, the objective of this paper is to examine the physical environment of Ilo stream, the pollutants and extent of pollution and their effects on the stream and the dwellers. The paper goes a little further to make some recommendations on how "to sanitize" the environment and make the best use of the stream and its water. At least, this is a good source of water that could be put into use to meet very many needs in the immediate environment of Ilo stream.

The paper is organized into nine (9) parts. The first two parts are introduction and methodology applied for data and information collection. Part three describes the location, position and physical environment of Ilo stream. Part four gives descriptive analysis of the samples collected. The fifth part describes the sources of pollutants and extent of pollution of Ilo stream, parts six and seven discusses the findings and the consequences of polluted water and pollutants. The last two parts gave some recommendation and concludes. The paper does not go into details of waste management nor dwell 


\section{Kofo. A. Aderogba (Mrs.) and Michael. A. Obafemi / IOSR Journal of Engineering (IOSRJEN)}

www.iosrjen.org

ISSN : 2250-3021

Vol. 2 Issue 2, Feb.2012, pp.273-279

into detail biochemical analysis of wastes and water. Unfamiliar technical jargons that would have made the paper uninteresting to readers were avoided.

\section{METHODOLOGY}

The research span through a period of three years - three dry and three wet seasons. Samples of Ilo stream water were collected from ten different points at an interval of about twenty meters apart. The identification of the point of collection was guided purposely and made to coincide with the followings:

- $\quad$ First, a location of about $21.20 \mathrm{~m}$ before Ogun State Hotel where an old bridge crosses the river;

- $\quad$ The point where waste water from Ogun State Hotel joins the stream;

- Under a group of bamboo trees; where there are large quantity of droppings of bamboo leaves

floating or submerged in the water;

- Location where there are daily and hourly spiritual bathing with different chemicals and substances (perfumes, incenses, soaps, and others);

- $\quad$ The upper and lower parts of the stream immediately before and after the Sango-Agege Express Way crosses the stream;

- The point around the slaughter where wastes from the abattoir are constantly being dumped;

- Location where there is a concrete block making industry - it's debris are constantly being washed into the stream;

- A point where there is a gas refilling plant located close to the right boundary of the stream; and

- A location that is relatively free of human activities and there seem to be a natural environment.

As the brief description of each point goes, they all have remarkable attributes that informed the need for taking the sample there and then. Hence, the immense and appropriate contributions to the robust success of the results obtained.

The samples collected were, each time, preserved and carefully transported for analysis at the Water Laboratory of Eleme Petrochemicals Company Limited (A Subsidiary Company of Nigeria National Petroleum Corporation), Port Harcourt. The results for each point and season were summarized; and the summary is as shown in the subsequent part of this work. The research also visited, observed and took notes of several activities, changes and occurrences in the Study Area and along the stream. Members of the public were interviewed and so also the Chief Executive Officers of Ogun State Hotel, Ota, Ilo Abattoir, Oando Filling Station and a number of some other establishments there. They all provided data and information about the activities vis-à-vis wastes that are generated. They responded to questions on the sources of water they use, waste management and their predicaments in respect of all of these.

\section{LOCATION, POSITION AND THE ENVIRONMENT:}

Ilo stream is one of the major streams and rivers that drain Ado-Odo Ota Local Government Area of Ogun State. It takes its source from within the Local Government Area. It flows south-westward through the boundary of Lagos and Ogun State, and into Lagos State. It is confined within the steep v-shaped valley of Ogun State to its right and Lagos State to its left. The stretch is given different local names at different locations. It should be of interest to note that the river is actually the boundary between Lagos and Ogun States in this area. Traditionally, it was the only source of water after rain and dew before the advent of pipe borne water, bore holes, wells, sachet and bottled waters, and water tankers. Even then, because the impact of the modern technology has not been well integrated nor felt, the communities still depend on the traditional source (Ilo stream) for water supply. The stream serves well over fifteen (15) communities from both Ado-Odo Ota and Ijaiye-Ojokoro Local Government Areas. These communities are not connected to any public pipe borne water; bore holes and wells are somehow beyond the reach of many. But to elucidate on what the communities use the water for, Table I explains: A community/household use it for more than one purpose. An estimated $85 \%$ members of the community use it for local industrial production, $58 \%$ for religion purposes and $28 \%$ for waste disposal. $23 \%$ use it for fishing and farming, $13 \%$ use it for recreation, and as much as $26 \%$ depend on it for domestic consumption.

Table I: Importance of Ilo Stream (An Estimate)

\begin{tabular}{|l|c|}
\hline Uses & Estimated \% Proportion of Dependence \\
\hline Religion & 58 \\
Farming/Fishing & 23 \\
Local Industry & 85 \\
Recreation & 13 \\
\hline
\end{tabular}


Kofo. A. Aderogba (Mrs.) and Michael. A. Obafemi / IOSR Journal of Engineering (IOSRJEN) www.iosrjen.org

ISSN : 2250-3021

Vol. 2 Issue 2, Feb.2012, pp.273-279

\begin{tabular}{|l|c|}
\hline Domestic consumption & 26 \\
Waste Disposal & 28 \\
Others (Specified) & 15 \\
\hline
\end{tabular}

\section{Source: Field Work.}

As at today, the situation is fast changing - the forests around it have been cleared, the water is diminishing; the channel is getting wider and shallow. The water is getting polluted and it is becoming unsuitable for any purpose. The current poor (polluted) conditions are described somewhere below.

\section{THE WATER SAMPLES:}

Table II shows the summary of all the parameters observed and compared with the WHO permissible standards. But the following should be of paramount importance to the results:

- The World Health Organization (WHO) limits are being adopted as the guidelines for Federal

Environmental Protection Agency (FEPA), and as standards for Nigeria;

- $\quad$ Fluoride $\left(\right.$ as $\left.\mathrm{F}^{+}\right)$depend on temperature i.e. it varies with temperature (and with seasons);

- Certain concentrations of some of the elements affect the concentration of some others;

- Aside seasonal variation, temperature change do affect the levels of concentration of some of the elements (parameters); and

- Concentration of Magnesium depends on the concentration of sulphate at a particular period.

By and large, the colour of the water is mostly grey - green. In the dry season, it tends to become brown-black. Turbidity (29.00 units), organic matter (24.00) and "very dangerous to health" phenolic compound (0.002) are far more than the WHO permissible standards. Similarly, Fluoride as $\mathrm{F}^{2+}(2.20)$, Nitrate as $\mathrm{NO}_{3}(72.50)$, Copper as $\mathrm{Cu}^{2+}(1.01)$, Iron as $\mathrm{Fe}^{2+}(1.10)$ and Chloride as $\mathrm{Cl}(640)$ are also high in concentration - $\mathrm{mg} / \mathrm{l}$. Some of the elements (and parameters) are more than double the WHO permissible values. Magnesium as $\mathrm{Mg}^{2+}$ (165.50) Hydrogen Sulphate as $\mathrm{H}_{2} \mathrm{~S}(0.60)$, Anionic Detergent (3.20), Zinc as $\mathrm{Zn}^{2+}(10.01)$ and Copper as $\mathrm{Cu}^{2+}(1.10)$ fall within this category - see Table II. Inadvertently therefore, the water has been badly polluted: the concentrations of the elements are far more than the permissible standards of the World Health Organization. But, what are the sources and nature of these pollutants that have rendered the water this useless.

Table II: Comparison of Ilo Water Parameters with WHO Standard. (mg/l)

\begin{tabular}{|c|c|c|}
\hline Parameter & WHO permissible standard & Sample Reading \\
\hline Colour & Nil & Grey/green \\
\hline Turbidity Units & 5.00 & 29.00 \\
\hline Organic Matter & 0.50 & 24.00 \\
\hline Phenolic Compound (as phenol) & 0.001 & 0.002 \\
\hline Fluoride $\left(\right.$ as $\left.\mathrm{F}^{2+}\right)$ & 1.70 & 2.20 \\
\hline Nitrite $\left(\right.$ as $\mathrm{NO}_{3}$ ) & 50.10 & 72.50 \\
\hline $\operatorname{Cod}(\mathrm{Mg} 2 / \mathrm{l})$ & & 280.00 \\
\hline PH & $6.5-8.5$ & 9.01 \\
\hline BOD (Mgo2/l) & - & 250.00 \\
\hline Copper (as $\mathrm{CU}^{2+}$ ) & 0.50 & 1.01 \\
\hline Iron $\left(\right.$ as $\left.\mathrm{Fe}^{2+}\right)$ & 0.10 & 1.10 \\
\hline Manganese (as $\mathrm{Mn}^{2+}$ ) & 0.50 & 0.75 \\
\hline Zinc (as $\mathrm{Zn}^{2+)}$ & 5.00 & 10.01 \\
\hline Magnesium (as $\mathrm{Mg}^{2+)}$ & 50.00 & 165.50 \\
\hline Sulphate (as $\mathrm{SO} 4^{2-}$ ) & 150.00 & 240.00 \\
\hline Hydrogen Sulphate (as H2S) & 0.05 & 0.60 \\
\hline Chloride (as $\mathrm{Cl}$ ) & 600.00 & 640.00 \\
\hline Anionic detergent & 0.20 & 3.20 \\
\hline Ammonia (as $\mathrm{NH}_{4}$ ) & 0.50 & 0.91 \\
\hline Calcium $\left(\right.$ as $\left.\mathrm{Ca}^{2+}\right)$ & 75 & 110.00 \\
\hline
\end{tabular}

Source: WHO and Field Work. 
Kofo. A. Aderogba (Mrs.) and Michael. A. Obafemi / IOSR Journal of Engineering (IOSRJEN) www.iosrjen.org

ISSN : 2250-3021

Vol. 2 Issue 2, Feb.2012, pp.273-279

Table III: Sources of Pollution to Ilo Stream.

\begin{tabular}{|l|r|}
\hline Sources of pollution & Estimated \% contribution \\
\hline Organic Wastes from Industrial plants & 20.50 \\
Inorganic Wastes from Industrial plants & 14.50 \\
Unknown Chemicals & 9.00 \\
Heat from Industrial Discharges & 2.50 \\
Municipal Wastes & 18.50 \\
Agricultural Wastes & 9.00 \\
Sediments From Land Erosion & 19.50 \\
Acidic Rain & 2.00 \\
Oil Spills \& Contribution from Water Routine & 3.00 \\
Operations/ Others & 1.50 \\
& \\
& \\
\hline Source: Field Work & \\
\hline Total & $\mathbf{1 0 0 . 0 0}$ \\
\hline
\end{tabular}

\section{SOURCES OF POLLUTION AND CRISIS:}

The classification of water pollutant used by Vesilind and Piere (1982) and as described by Umeh, (2000: 44) is applied. An estimated percentage contribution of each class of pollutants is shown in Table III. Over $20 \%$ of the pollution could be traced to organic wastes from industrial plants and hotels around (and from both sides of the stream). Inorganic wastes that include cans, roofing sheets, pans etc and all metallic relics contributed $14.50 \%$. Sediments from land erosion and municipal wastes contributed $19.50 \%$ and $18.50 \%$ respectively; see Table III. Acid rain, though seasonal, contributed 2\%. Agricultural wastes from the surrounding farms, piggeries, fish ponds and poultries contributed 9.50\%. The municipal wastes include the daily abattoir activities at the right bank of the stream (and South West of the old Toll Gate on Agege-Sango Express Way). Defecation, washing and bathing in the stream also contributed to this $19.50 \%$, See Table III. Also included in the municipal wastes are the indiscriminate dumping of junks and refuse from homes and commercial centers from far and near this location. There are large spans of refuse dumps and dung hills additionally receiving large quantity of wastes on hourly basis. It is all of these and many others that have contributed pollutants and waste into this water body. But, they are in what forms? They are in the quantity and levels that are not tolerable for consumption. It is a crisis to all life forms and the general environment in its totality.

\section{DISCUSSIONS:}

Suspended solids, free chloride, fluoride, phosphorous, oil and grease, high pH, BOD, chromium, cyanide, phenol, iron, copper, zinc, Nickel, settle able solids, toxic materials, pesticides, total coliforms, abnormal temperature at various times, urea and other organic nitrogen compounds are present in abnormally high proportions. Others are total dissolved solids, traces of aluminum, ammonia, tin, water breaking, synthetic resins, TOC, heavy metals, colour variations, mercaptants, turbidity, hardness, organic chloride and others are evident and quite abnormal in proportion and or level. All of these have severe effect on the water quality. For instance, the higher energy organic materials discharged into the stream are decomposed and thus lead to a number of changes particularly down stream from the point of discharge:

- $\quad$ oxygen is used at a greater rate than before the pollution occurred so that the Dissolved Oxygen (DO) level drops; and

- the rate of solution of oxygen from air (recreation) increases.

Mitchell (1972) and Warren (1971) as quoted by Uchegbu (2000) assert that the rate of recreation does not match the rate of oxygen depletion so as to prevent a total depletion of oxygen from such stream. Such stream is then said to become anaerobic. Even though the dissolved oxygen may not drop to zero and the stream may recover without experiencing a period of anaerobic (Mitchell 1972), the following marks of aerobic conditions are obvious: 


\section{Kofo. A. Aderogba (Mrs.) and Michael. A. Obafemi / IOSR Journal of Engineering (IOSRJEN)}

www.iosrjen.org

ISSN : 2250-3021

Vol. 2 Issue 2, Feb.2012, pp.273-279

- Among other gases, ammonia and hydrogen sulphide are formed since oxygen is probably so low (or absent) to act as hydrogen acceptor;

- Aside those gases that will dissolve, others attach and attack themselves as bubbles to hunks of block solid materials (benthic deposits). These are characteristically the floating solids and gas bubbles found on the water surface;

- The colour has turned brown and sometimes black. It is only at a few times particularly during raining seasons that it looks grey brown and turbid;

- The presence of long filamentous fungi and algae growth are not uncommon throughout the year. They cling to rocks and soil at the banks throughout the length of the stream;

- $\quad$ Down stream, from the point of gross pollutions, there is decreased turbidity, settled solid matters and low DO; and

- There is decrease in fish and other life forms in the water.

Apart from the aerobic conditions of the stream, other conditions are obvious and alarmingly acknowledged by this author in some other similar works on streams and rivers in this area.

\section{CONSEQUENCES OF POLLUTION AND POLLUTANTS:}

Continuous discharge and dumping of highly polluted domestic and industrial effluents and other wastes into the environment have very devastating, and hazardous health effects on plant and animals that come in contact with the polluted natural water of the Ilo stream at one time or the other. It also completely rendered the water useless to the inhabitant of the locality. The consequences of the pollution have been very grievous:

- The water has become unfit for consumption domestically and industrially;

- $\quad$ even the slaughter can no longer depend on or use the water for washing and preparing beef for marketing and sales;

- $\quad$ Most aquatic life forms have been wiped out and thus changed the life forms in the micro environment;

- There is characteristically offensive odour at different spots along the stream;

- $\quad$ Aesthetically the entire environment of the water throughout that stretch has been made to become ugly;

- It is likely that any studies by schools and colleges to learn about aquatic ecosystems may not be able to give a true picture of the expected;

- The stream is diminishing in water content, depth and the width getting wider since debris and undissolved wastes are continuously getting deposited and sealing the channel gradually; and

- The spiritualists, the slaughter (abattoir) and the local dwellers that depend on water from this stream have to fend for alternatives at extra costs (of time, labor and money).

Whereas, this is "a resource" that is well located outside the hustling and bustling of Sango and Ota in Ogun State, and the ever busy Lagos metropolis. In other words, the water and its environment could have been developed to meet domestic, industrial, agricultural, recreational, educational, spiritual other needs - if only it could be conserved, preserved and maintained.

\section{POLLUTION CONTROL AND WATER MANAGEMENT:}

Collection and management of wastes is relatively new in Nigeria and among Nigerians. But generally, well established systems of waste management will prevent waste generation, save money in waste haulaging, disposal and recycling fees, conserves valuable landfill space and reduces energy and resources use. Above all, it will drastically reduce pollution of the land and, of course, water - all over. Management of waste water before discharge into the environment is to reduce their pollution burden to acceptable limit in order to protect the natural environment and ultimately the receiving water body.

Therefore, there may be need to organize treatment of the waste water and or the effluents being discharged into the stream and rivers including the Ilo stream. This may involve a series of stages of treatment: pre treatment, primary treatment, secondary treatment and tertiary treatment. An elaborate explanation of these is beyond the scope of this paper. Suffice it to mention, however, that if the waste water could be classified, it could be further treated by disinfection with chlorine, ozone or any strong disinfectant. It could then be filtered with cloth or sieve. Large scale filtration will definitely require sand filter bed or more sophisticated technology.

But as at now, and at the interim, the Federal, State and Local governments as well as public and private conglomerates would need to encourage the use of wells and boreholes. Not many individuals and families can afford it. The three tiers of government can give their massive support. Both sources appear to be the most reliable alternatives as of now (Aderogba, 2005). Some treatment of the water before consumption will go a long way to keep it fit. 


\section{Kofo. A. Aderogba (Mrs.) and Michael. A. Obafemi / IOSR Journal of Engineering (IOSRJEN) www.iosrjen.org \\ ISSN : 2250-3021}

Vol. 2 Issue 2, Feb.2012, pp.273-279

However, emphasis should be placed on the supply and distribution of treated potable water by State and Federal governments in particular. It will generally lead to constant potable water supply to meet every need-not only in this Study Area but generally in Ogun State and the nation at large. Federal and State Water Boards and Water Corporations should not go into extinction. It is time they woke up from their long slumber to their responsibilities.

Pollution of natural water from Ilo stream, like in most other rivers and streams in the state (and generally in Nigerian) should be tackled head on: water bodies should be preserved, conserved and maintained to support all needs and for possible longevity. Wastes should be controlled and managed by individuals, groups, governments and government agencies at homes, in industries, on farms, at commercial centers, and others in order not to find their ways to the points where water would be polluted and rendered useless.

\section{CONCLUSION:}

Management of wastes and other pollutants in water, air and on land are such that require collection, transportation, disposal, and treatment and probably recycling (if technology permits). For preservation and maintenance of Ilo stream in this direction and to be "stable and habitable" and or become useful environment call for serious attention. Huge financial involvement; and individual and government commitments are also required. Indiscriminate dumping of wastes and junks into erosion passages, sewage channels and gutters should stop.

The Federal Government Agencies and all other relevant government parastatals should enforce the decree and policy guidelines as enacted and fashioned out in 1989, 1991 and 1992 particularly as it relates to Environmental Impact Assessment (EIA) - 1992 Decree no 86 by the Federal Environmental Protection Agency. Specifically, legal muscles should be given to EIA Decree no 86 of 1992 for the enforcement of the various policy provisions on the need for studies on the environmental impact of both public and private sector projects. Further trust in dealing with the issues of environmental quality is made by the Urban and Regional Planning Decree no 88 of 1992. This should also be squarely enforced. Section 33 of the decree provides that a developer shall submit application for development to the Development Control Department together with a detailed EIA for an application for the followings:

- A residential land in excess of two hectares;

- Permission to build or expand a factory or for the construction of an office building in excess of four floors or 5,000 square meters of lettable space; and

- Permission for a major recreational development.

On these notes, a project can be approved, rejected or delayed if the conditions are not met. It is high time the provisions of these decree are fully enforced. Where necessary and appropriate, legislature may have to review them. The syndrome whereby governments and government parastatals and agencies will construct wells and bore holes and spend four times of its cost on commissioning should be over. Potable water and clean environment are so essential in human settlement - for social, economic, recreational, religious, domestic, and industrial or whatever use. It is very doubtful if any community can exist and survive without potable water. Therefore, attention should be shifted to preservation, conservation and maintenance of every source of water to be able to meet the demand for potable water in human settlement and at the required quantity and place too. At the same time, the generality of the environment need to be respected, conserved, preserved and maintained.

\section{References:}

Adeniyi, E. O. (1986) Development and Environmental Management in Nigerian Industries. Ibadan: NISER.

Aderogba, K. (1994) Water Supply Situations in Nigeria. in Journal of Arts And Social Sciences. VOL. 1 No.1' pp. 1 11.

Aderoba, K. A. (2005) "Ground Water Development in Nigeria: A Case of Abeokuta-Ewekoro-Ifo-

Axis in Ogun State". International Journal of Environmental Issues. Vol. 2 Nos. 1 and 2, pp. $51-68$.

Aina, O. A. (1989) "Environmental Pollution Problems" The Nigeria Business Law and Practice Journal Notes on

Environmental Edict No 13 of Lagos State.

Aina, O. A. (1994) Local Actions for Developing Global Environmental Crisis" Address in Commemoration of the 1994 World Environment Day. Lagos. FEPA

Federal Environment Protection Agency (1988) Federal Environmental Protection Agency Decree 1988. Lagos. FEPA. Federal Environmental Protection Agency (1991) Guidelines and Standards for Environmental Control in Nigeria Lagos. FEPA.

Federal Environmental Protection Agency (1992) Environmental Impact Assessment Decree (No $\underline{86)}$ Supplement to Critical Gazette Extraordinary No. 73 . Vol. 179 Lagos. FEPA 
Kofo. A. Aderogba (Mrs.) and Michael. A. Obafemi / IOSR Journal of Engineering (IOSRJEN)

www.iosrjen.org

ISSN : 2250-3021

Vol. 2 Issue 2, Feb.2012, pp.273-279

Federal Republic of Nigeria (1991) Guidelines and Standards for The Petroleum Industry. Lagos. of Petroleum Resources.

Federal Republic of Nigeria (1992) Urban and Regional Planning Decree (No 88) 1992 Official Gazette, No

Department

Vol. 7 Lagos. Federal Government Dress.

Harlow, R and Morgan, S. (2002) Garbage and Recycling New York. John Willey.

Lynne, (2002) A River and Wild: An Environmental History. New York. John Willy.

Mann, R. E. (1979) Environmental Impact Assessment New York. John Willey and Sons.

Mayor, U. (2004) Chemistry of Hazardous Material. Occasional Paper No 14. London. Water Issue

School of Countation and African Studies University of London.

Marq,de vilhiers (2001) Water the Fate of our Most Precious Resource. International Journal of Water Resources

Development. Vol. 16 No.1 (March).

Olokesusi, F. (1992) Environmental Impact Assessment in Nigeria: Current Situations and Directions for the Future. Journal of Environmental Management Vol. 35 pp. 171.

Oluwande, P. A. (1983) "Assessment of Solid waste Management Problems in China and Africa" in _ J. R.

Holmas (Ed) Practical Waste Management. London John Willey and Sons Ltd.

Royle, E. (2005) Garbage Land: On the Secret Trail of Trash. Siri Lanka. International Water

Institute.

Uchegbu, S. N. (2000) Environmental Management in Nigeria: Practical Examples. Lagos. Computer Edge Publishers.

Umeh, L. C. and Uchegbu S. N. (1997) Principles and Procedure of Environmental Impact $\quad$ Assessment (EIA).

Lagos. Computer Edge Publishers.

Womack, J. P. and Jones, D. F. (2003) Lean Thinking: Banish Waste and Create Wealth in their Corporation. Siri

Lanka. International Water Management. 